\title{
STUDI HUBUNGAN ANTARA SEBARAN DAN BEBAN PENCEMARAN RADIOAKTIVITAS SAMPEL LINGKUNGAN TERHADAP BAKU MUTU DAN DAYA TAMPUNG SUNGAI CODE YOGYAKARTA
}

\author{
Agus Taftazani, Muzakky \\ PTAPB - BATAN, Yogyakarta
}

\begin{abstract}
ABSTRAK
STUDI HUBUNGAN ANTARA SEBARAN DAN BEBAN PENCEMARAN RADIOAKTIVITAS TERHADAP BAKU MUTU DAN DAYA TAMPUNG PADA SUNGAI CODE YOGYAKARTA. Telah dilakukan analisis hubungan antara sebaran dan beban pencemaran aktivitas gross $\beta$ dan radionuklida alam dalam sampel air serta sedimen dari 11 stasiun-pengamatan sungai Code terhadap baku mutu dan daya tampung sungai Code Yogyakarta. Sampel konsentrat air dan serbuk sedimen kering-homogen lolos 100 mesh diukur gross $\beta$ dengan detektor GM serta diidentifikasi radionuklida dengan spektrometer $\gamma$ (detektor HPGe dan software Maestro II). Data radioaktivitas dianalisis secara deskriptif dengan histogram untuk melihat pola penyebaran data. Data beban pencemaran, baku mutu dan daya tampung sungai Code dianalisis secara deskriptif dengan diagram garis untuk melihat pola hubungan antara beban pencemaran dan daya tampung sungai. Hasil pengamatan sampel air dan sedimen di 11 stasiun-pengamatan menunjukkan telah terdeteksi radionuklida alam pemancar $\gamma:{ }^{210} \mathrm{~Pb},{ }^{212} \mathrm{~Pb},{ }^{214} \mathrm{~Pb},{ }^{226} \mathrm{Ra},{ }^{208} \mathrm{Tl},{ }^{214} \mathrm{Bi},{ }^{228} \mathrm{Ac}$, dan ${ }^{40} \mathrm{~K}$. Berdasarkan hasil analisis yang diperoleh dapat disimpulkan bahwa pola penyebaran aktivitas rerata gross $\beta$ dan $\gamma$ semakin meningkat dari hulu ke hilir sungai Code, baik pada sampel air maupun sampel sedimen. Hasil analisis beban pencemaran, baku mutu dan daya tampung aktivitas radionuklida ${ }^{210} \mathrm{~Pb}$, ${ }^{212} \mathrm{~Pb},{ }^{226} \mathrm{Ra}$ dan ${ }^{228} \mathrm{Ac}$ ditunjukkan beban pencemaran lebih kecil dari baku mutu air sungai menurut keputusan Badan Pengawas Tenaga Nuklir 02/Ka-BAPETEN/V-99 tentang baku mutu radioaktivitas, berarti sungai Code masih memiliki daya tampung yang baik terhadap keempat radionuklida tersebut.

Kata Kunci: Beban pencemaran, bakumutu, daya tampung, gross $\beta$, radionuklida alam.
\end{abstract}

\section{ABSTRACT}

STUDY OF RELATIONSHIP BETWEEN RADIOACTIVITY DISTRIBUTION, CONTAMINATION BURDE AND QUALITY STANDARD, ACCOMMODATE ENERGY OF CODE RIVER YOGYAKARTA. Study of relationship between distribution, contamination burden of gross $\beta$ radioactivity and natural radionuclide in water and sediment sample from 11 observation station Code river to quality standard and maximum capacity of Code river have been done. Natural radio nuclides identification and gross $\beta$ radioactivity measurement of condensed water, dry and homogeneous sediment powder (past through 100 mesh sieve) samples have been done by using $\gamma$ spectrometer and GM counter. Radioactivity data was analyzed descriptive with histogram to show the spreading pattern of data. Contamination burden data, quality standard and maximum capacity of river Code was to descriptive analyzed by line diagram to knowing relationship between contamination burden, quality standard, and maximum capacity of Code river. The observation of water and sediment at 11 observation station show that the remitter natural radionuclides: ${ }^{210} \mathrm{~Pb},{ }^{212} \mathrm{~Pb}$, ${ }^{214} \mathrm{~Pb},{ }^{226} \mathrm{Ra},{ }^{208} \mathrm{Tl},{ }^{214} \mathrm{Bi},{ }^{228} \mathrm{Ac}$ and ${ }^{40} \mathrm{~K}$ were detected. The analytical result conclusion was that the pattern spread of average activity gross $\beta$ and $\gamma$ were increase from upstream to downstream of the Code river samples. Contamination burden, quality standard and maximum capacity of radionuclide activity of ${ }^{210} \mathrm{~Pb}$, ${ }^{212} \mathrm{~Pb},{ }^{226} \mathrm{Ra}$ and ${ }^{228} \mathrm{Ac}$ were more smaller than quality standard of river water according to regulation of Nuclear Energy Regulatory Agency 02/Ka-BAPETEN/V-99 concerning quality standard of radioactivity. It's mean that Code river still in good contamination burden for the four radionuclides.

Key words: Contaminant burden, quality standard, accomodate energy, gross $\beta$, natural radionuclide 


\section{PENDAHULUAN}

Sumber pencemar sungai tidak terlepas dari pengaruh pemanfaatan lahan serta perilaku penduduk dalam membuang sampah ataupun limbah yang berasal dari kegiatan pertanian, industri, jasa dan permukiman. Berdasarkan laporan Prokasih (Program Kalibersih) Propinsi DIY tahun 2005, dampak negatif yang dengan mudah dapat dipantau dan dirasakan di sepanjang sungai antara lain seperti air sungai dan air sumur yang tercemar, kualitas udara yang tercemar, dan program Prokasih yang belum berhasil. Berangkat dari permasalahan diatas, dalam penelitian ini akan dilakukan analisis statistik deskriptif berdasarkan hasil penelitian A. Taftazani bulan Agustus $2005^{[1]}$ yaitu besarnya aktivitas rerata parameter aktivitas gross $\beta$ dan radionuklida alam pemancar $\gamma$ sampel air dan sedimen sungai Code di 11 titik stasiun-pengamatan. Analisis statistik deskriptip ini untuk mengetahui hubungan antara Beban pencemaran (BP), Baku Mutu (BM) dan Daya Tampung (DT) berdasarkan peraturan yang berlaku (PPRI No. 82 Tahun $2001^{[2]}$, SK Men.KLH No 110/2003 ${ }^{[3]}$ dan SK. Kepala Badan Pengawas Tenaga Nuklir 02/Ka-BAPETEN/ $-99^{[4]}$ ).

Sumber pencemaran air di sekitar sungai Yogyakarta menurut A.Taftazani $2005^{[1]}$ yang diperkirakan berasal dari material letusan gunung merapi, dan limbah domestik (limbah rumah tangga dan rumah sakit), pemanfaatan lahan pertanian serta limbah industri yang berada di sepanjang sungai (lihat Gambar 1). Dari sumber-sumber pencemaran yang terdapat di daerah aliran sungai tersebut diperkirakan adanya kandungan unsur radioaktif (radionuklida) khususnya pada air dan sedimen sungai yang berpotensi untuk terjadi pencemaran radioaktif di lingkungan perairan sungai tersebut.

Pendefinisian istilah beban pencemaran (BP), baku mutu (BM) dan daya tampung (DT) mengacu SK Men.KLH No $110 / 2003^{[3]}$. Pada penelitian ini istilah dan besaran konsentrasi dari parameter kimia air diasumsikan sebagai besaran radioaktivitas yang mengacu baku mutu radioaktivitas menurut SK. Kepala BAPETEN tahun $1999^{[4]}$. Asumsi ini berdasarkan anggapan bahwa setiap air maupun sedimen alamiah (nature) selain mengandung unsur logam juga mengandung zat radioaktif alam. Diasumsikan setiap zat radioaktif dan unsur logam/ion logam tersebut saling larut atau saling campur dalam air/sedimen kemudian ikut mengalir bersama masuk ke sungai Code, sehingga neraca massanya dapat dihitung.

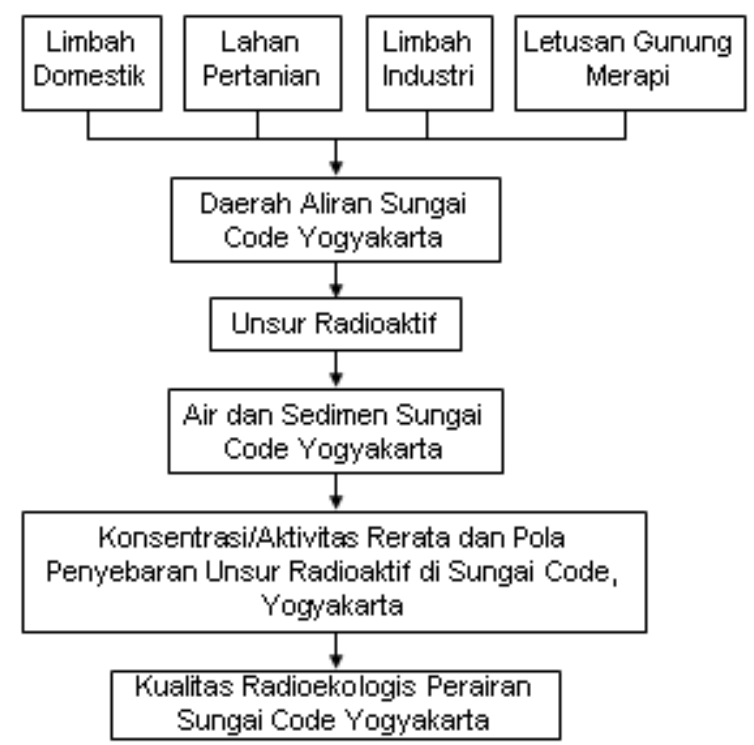

Gambar 1. Skema sumber radioaktivitas di Sungai Code Yogyakarta ${ }^{[1]}$

Beban pencemaran adalah nilai radioaktivitas dari parameter kimia air dari sampel yang diukur/diteliti dibandingkan dengan baku mutu air menurut Keputusan Kepala Badan Pengawas Tenaga Nuklir No. 02/KaBAPETEN/V-99 untuk radioaktivitas di lingkungan. Nilai radioaktivitas atau aktivitas jenis sampel air dan sedimen sungai Code dapat dihitung dengan mengacu pustaka Agus Taftazani $2002^{[6]}$. 
Studi hubungan antara sebaran dan beban pencemaran radioaktivitas sampel lingkungan terhadap baku mutu dan daya tampung sungai Code Yogyakarta

Baku mutu adalah batas atau aktivitas partikel/komponen yang diijinkan atau batas radioaktivitas maksimum unsur pencemar yang ditenggang adanya dalam suatu sumber daya tertentu sebagai unsur lingkungan hidup. baku mutu yang digunakan adalah baku mutu air sungai berdasarkan keputusan Kepala Badan Pengawas Tenaga Nuklir 02/Ka-BAPETEN/V-99 ${ }^{[4]}$ untuk radioaktivitas.

Daya Tampung adalah baik atau jeleknya kemampuan sungai untuk dapat menerima beban pencemaran radioaktivitas. Untuk menentukan daya tampung sungai terhadap beban pencemaran radioaktivitas adalah atas dasar beban pencemarnya yaitu nilai atau radioaktivitas dari parameter kimia air yang terukur dibandingkan dengan baku mutu air sungai berdasarkan Keputusan Kepala Badan Pengawas Tenaga Nuklir 02/Ka-BAPETEN/ $\mathrm{V}-99^{[4]}$ untuk radioaktivitas di lingkungan. Adapun rumus perhitungannya menurut SK. Men. KLH No. 110/2003 ${ }^{[3]}$ yang dimodifikasi sebagai berikut:

Penentuan daya tampung sungai dilakukan berdasarkan model matematika neraca massa, dengan rumus sabagai berikut :

$$
C R=\frac{\sum C i Q i}{\sum Q i}=\frac{\sum M i}{\sum Q i}
$$

keterangan :

$\mathrm{CR}=$ konsentrasi diganti dengan aktivitas rata-rata konstituen untuk aliran gabungan

$\mathrm{Ci}=$ aktivitas konstituen pada aliran ke $\mathrm{i}$

Qi = laju aliran ke i

$\mathrm{Mi}=$ massa konstituen pada aliran ke $\mathrm{i}$

Untuk menentukan daya tampung sungai terhadap beban pencemaran zat radioaktif adalah atas dasar beban pencemarnya yaitu nilai atau radioaktivitas dari parameter kimia air yang terukur dibandingkan dengan baku mutu air SK BAPETEN 02/Ka-BAPETEN/V-99. Apabila beban pencemarnya (radioaktivitas) masih jauh dibawah ambang batas yang dianjurkan baku mutu radioaktivitas maka daya tampung suatu sungai dapat dikatakan baik.dan memenuhi peruntukannya.

\section{Kondisi Daerah Penelitian}

Penelitian ini dilakukan dengan mengambil 11 titik stasiun yaitu dari hulu sampai hilir sungai Yogyakarta. Secara garis besar, sumber pencemar sungai dapat dilihat pada Tabel 1,2 dan Gambar 2.

Tabel 1. Koordinat pengambilan sampel sungai dan kondisi daerah penelitian

\begin{tabular}{|c|c|c|c|c|c|}
\hline Stasiun & Lokasi & Bujur Timur & Lintang Selatan & $\begin{array}{c}\text { Debit } \\
\left(\mathrm{m}^{3} / \text { detik }\right)^{*}\end{array}$ & $\begin{array}{c}\text { Kecepatan aliran, } \\
(\mathrm{m} / \text { detik })^{*}\end{array}$ \\
\hline 1 & J. Turgo, Purwobinangun & $110^{\circ}, 25^{\prime}, 34^{\prime \prime}$ & $07^{0}, 35^{\prime}, 5^{\prime \prime}$ & 0.0292 & 0.017 \\
\hline 2 & J. Boyong & $110^{\circ}, 24^{\prime}, 45^{\prime \prime}$ & $07^{0}, 37^{\prime}, 26^{\prime \prime}$ & 0.0701 & 0.023 \\
\hline 3 & J. Ngentak, Sinduharjo & $110^{\circ}, 23^{\prime}, 22^{\prime \prime}$ & $07^{0}, 43^{\prime}, 22^{\prime \prime}$ & 0.0974 & 0.0177 \\
\hline 4 & J. Ring Road Utara & $110^{\circ}, 22^{\prime}, 30^{\prime \prime}$ & $07^{0}, 45^{\prime}, 10^{\prime \prime}$ & 0.1316 & 0.044 \\
\hline 5 & J. Sardjito & $110^{\circ}, 22^{\prime}, 14^{\prime \prime}$ & $07^{0}, 46^{\prime}, 56^{\prime \prime}$ & 0.6167 & 0.062 \\
\hline 6 & J. Recobuntung, Tukangan & $110^{\circ}, 22^{\prime}, 11^{\prime \prime}$ & $07^{0}, 47^{\prime}, 39^{\prime \prime}$ & 0.6312 & 0.057 \\
\hline 7 & J. Tungkak & $110^{\circ}, 22^{\prime}, 29^{\prime}$ & $07^{0}, 48^{\prime}, 11^{\prime \prime}$ & 0.6075 & 0.058 \\
\hline 8 & J. Karangkajen & $110^{\circ}, 22^{\prime}, 30^{\prime \prime}$ & $07^{0}, 49^{\prime}, 32^{\prime \prime}$ & 0.7755 & 0.078 \\
\hline 9 & J. Ring Road Selatan & $110^{\circ}, 22^{\prime}, 31^{\prime \prime}$ & $07^{0}, 50^{\prime}, 11^{\prime \prime}$ & 0.5948 & 0.029 \\
\hline 10 & J. Ngoto & $110^{\circ}, 22^{\prime}, 33^{\prime \prime}$ & $07^{0}, 50^{\prime}, 32^{\prime}$ & 0.1658 & 0.04 \\
\hline 11 & J. Pacar, Wonokromo & $110^{\circ}, 22^{\prime}, 65^{\prime}$ & $07^{0}, 52^{\prime}, 22^{\prime \prime}$ & 0.0311 & 0.016 \\
\hline
\end{tabular}

Catatan: * = diukur pada bulan Agustus 2005 (musim Kemarau)

$\mathrm{J}=$ jembatan 
Studi hubungan antara sebaran dan beban pencemaran radioaktivitas sampel lingkungan terhadap baku mutu dan daya tampung sungai Code Yogyakarta.

Tabel 2. Identifikasi Sumber Pencemar sungai Code

\begin{tabular}{|c|c|c|c|}
\hline \multicolumn{2}{|r|}{ Stasiun } & \multirow{2}{*}{$\begin{array}{l}\text { Penggunaan } \\
\text { Lahan }\end{array}$} & \multirow{2}{*}{ Indikasi Sumber Pencemar } \\
\hline No & Lokasi & & \\
\hline 1 & $\begin{array}{l}\text { Turgo, } \\
\text { Purwobinangun }\end{array}$ & $\begin{array}{l}\text { Pertambangan } \\
\text { batu dan pasir }\end{array}$ & $\begin{array}{l}\text { Mata air langsung (dari sumbernya), material pasir, batu, tanah, dan lain- } \\
\text { lain }\end{array}$ \\
\hline 2 & Boyong & $\begin{array}{l}\text { Pertambangan } \\
\text { batu dan pasir }\end{array}$ & $\begin{array}{l}\text { Mata air langsung (air dari sumbernya), material pasir, batu, tanah, dan } \\
\text { lain-lain }\end{array}$ \\
\hline 3 & $\begin{array}{l}\text { Ngentak, } \\
\text { Sinduharjo }\end{array}$ & $\begin{array}{l}\text { Pertanian dan } \\
\text { permukiman }\end{array}$ & $\begin{array}{l}\text { Adanya air irigasi masuk sungai, limbah cair dari pertanian (pestisida), } \\
\text { limbah cair dari rumah tangga, limbah padat berupa sampah domestik }\end{array}$ \\
\hline 4 & Ring Road Utara & Permukiman & $\begin{array}{l}\text { Adanya limbah cair dari rumah tangga, limbah padat berupa sampah, } \\
\text { adanya saluran air kotor dari rumah tangga dan tempat pembuangan } \\
\text { sampah }\end{array}$ \\
\hline 5 & Sardjito & $\begin{array}{l}\text { Jasa dan } \\
\text { permukiman }\end{array}$ & $\begin{array}{l}\text { Adanya buangan air limbah dari jasa berupa limbah dari hotel dan rumah } \\
\text { sakit serta adanya buangan limbah dari rumah tangga }\end{array}$ \\
\hline 6 & $\begin{array}{l}\text { Recobuntung } \\
\text { Tukangan }\end{array}$ & $\begin{array}{l}\text { Jasa dan } \\
\text { permukiman }\end{array}$ & $\begin{array}{l}\text { Adanya buangan air limbah dari jasa berupa limbah dari hotel dan rumah } \\
\text { sakit serta adanya buangan limbah dari rumah tangga }\end{array}$ \\
\hline 7 & Tungkak & $\begin{array}{l}\text { Industri dan } \\
\text { permukiman }\end{array}$ & $\begin{array}{l}\text { Adanya air limbah dari rumah tangga (limbah domestik), serta limbah dari } \\
\text { industri }\end{array}$ \\
\hline 8 & Karangkajen & $\begin{array}{l}\text { Industri dan } \\
\text { permukiman }\end{array}$ & $\begin{array}{l}\text { Adanya air limbah dari rumah tangga (limbah domestik), serta limbah dari } \\
\text { industri }\end{array}$ \\
\hline 9 & $\begin{array}{l}\text { Ring Road } \\
\text { Selatan }\end{array}$ & $\begin{array}{l}\text { Jasa dan } \\
\text { permukiman }\end{array}$ & $\begin{array}{l}\text { Adanya buangan air limbah dari jasa berupa limbah dari rumah sakit dan } \\
\text { adanya buangan air dari rumah tangga }\end{array}$ \\
\hline 10 & Ngoto & $\begin{array}{l}\text { Industri dan } \\
\text { permukiman }\end{array}$ & $\begin{array}{l}\text { Adanya air limbah dari rumah tangga (limbah domestik), serta limbah dari } \\
\text { industri }\end{array}$ \\
\hline 11 & $\begin{array}{l}\text { Pacar, } \\
\text { Wonokromo }\end{array}$ & $\begin{array}{l}\text { Permukiman } \\
\text { dan pertanian }\end{array}$ & $\begin{array}{l}\text { Adanya air irigasi masuk sungai, limbah cair dari pertanian (pestisida), } \\
\text { limbah cair dari rumah tangga, limbah padat berupa sampah }\end{array}$ \\
\hline
\end{tabular}

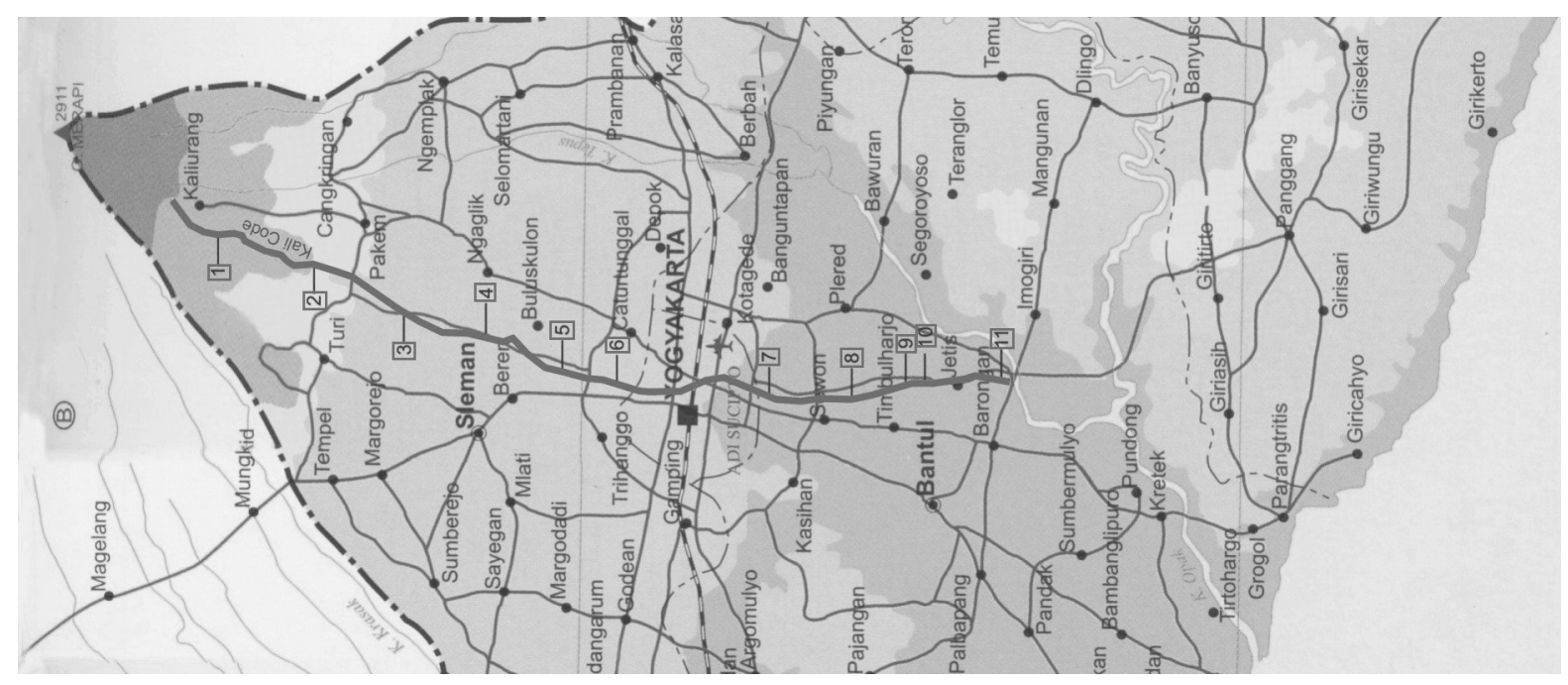

GAMBAR 2. PETA DAS CODE YOGYAKARTA (SUMBER : BAPPEDA DIY, 2005)

\section{TATA KERJA}

\section{Bahan Dan Alat}

Bahan penelitian adalah sampel air dan sedimen yang diambil dari 11 stasiun pengamatan disepanjang sungai Code Yogyakarta. Bahan kimia, standar dan alat yang dipakai mengacu pada Agus Taftazani $1997^{[7]}$. 
Studi hubungan antara sebaran dan beban pencemaran radioaktivitas sampel lingkungan terhadap baku mutu dan daya tampung sungai Code Yogyakarta

\section{Metode Kerja}

Metode kerja meliputi cara sampling, preparasi sampel, pengukuran radioaktivitas dan perhitungan mengacu Agus Taftazani $2002^{[6]}$. Berdasarkan analisis lokasi dari Agus Taftazani $2005^{[0]}$ maka 11 stasiun pengamatan dapat dikelompokan menjadi 3 kelompok: hulu (stasiun 1, 2, dan 3), tengah (stasiun 4, 5, 6, 7, dan 8) dan hilir (stasiun 9, 10 dan 11).

\section{HASIL DAN PEMBAHASAN}

Data penelitian diolah dari penelitian yang dilakukan dengan mengambil 11 titik stasiun yaitu dari hulu sampai hilir sungai Code Yogyakarta (Tabel 1 dan 2). Berdasarkan hasil penelitian tersebut diperoleh data hasil analisis dan perhitungan rerata parameter aktivitas gross $\beta$, aktivitas rerata radionuklida alam pemancar $\gamma$ terhadap sampel air dan sedimen sebagaimana dalam Gambar 3.

\section{Pola sebaran aktivitas Gross Betha $(\beta)$}

Dari hasil pengamatan dapat diketahui bahwa aktivitas rerata gross $\beta$ tertinggi dari sampel air maupun sedimen sungai adalah pada daerah hilir. Dapat dilihat pada gambar histogram berikut:
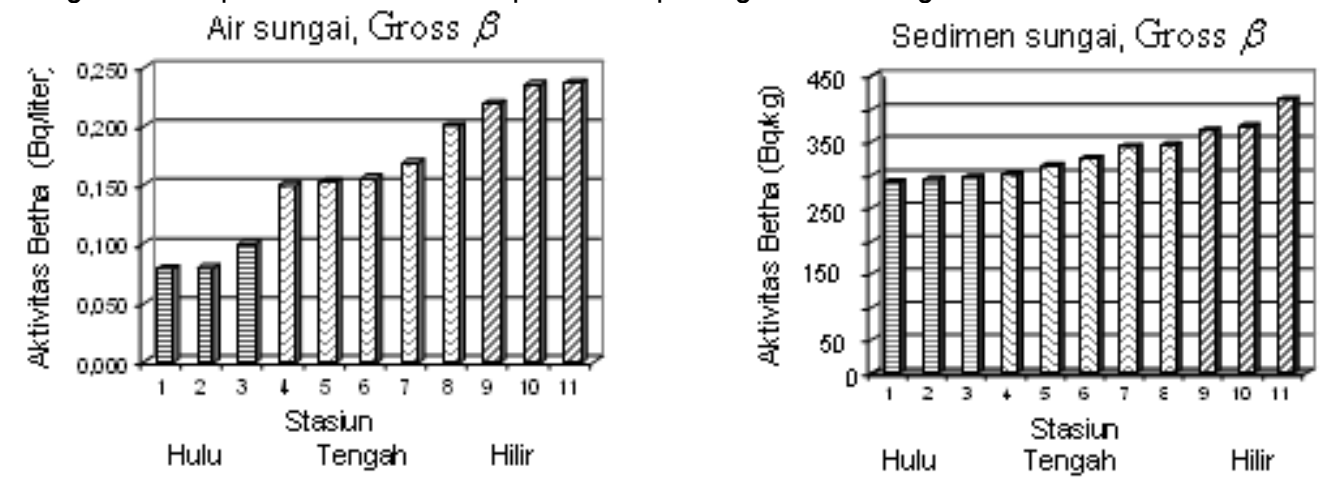

Gambar 3. Pola sebaran gross Betha $(\beta)$ pada sampel air dan sedimen dari hulu sampai hilir.

Dari Gambar 3, hasil pengukuran gross $\beta$ dapat diamati sebagai berikut,

1. Tingkat aktivitas gross $\beta$ di daerah Hulu Sungai (meliputi daerah di sekitar stasiun 1 Turgo Purwobinangun, stasiun 2 Boyong Bawah, dan stasiun 3 Ngentak) sampel air sebesar 0,079-0,1 Bq/liter dan sampel sedimen 290,084 - 295,359 Bq/kg.

2. Tingkat aktivitas gross $\beta$ di daerah Tengah Sungai (meliputi daerah di sekitar stasiun 4 Ring Road Utara, stasiun 5 Sardjito, stasiun 6 Recobuntung Tukangan, stasiun 7 Tungkak, dan stasiun 8 Karangkajen) untuk sampel air sebesar 0,150-0,2 Bq/liter dan sampel sedimen sebesar 300,633 - 345,464 Bq/kg.

3. Tingkat aktivitas gross $\beta$ di daerah Hilir Sungai (meliputi daerah di sekitar stasiun 9 Ring Road Selatan, stasiun 10 Abang Ngoto, serta stasiun 11 Pacar Wonokromo) untuk sampel air sebesar 0,219 - 0,237 Bq/liter dan sampel sedimen sebesar 366.561 - $414.030 \mathrm{~Bq} / \mathrm{kg}$

Hal ini menunjukkan bahwa semakin ke Hilir Sungai nilai pencemaran aktivitas gross $\beta$ baik untuk sampel air maupun sedimennya semakin meningkat, yang disebabkan karena lebih banyak dan beragamnya aktivitas kehidupan yang dilakukan di daerah hilir jika dibandingkan dengan di daerah hulu yang relatif masih bersih dan jauh dari pencemaran. Terlihat juga kenaikan radioaktivitas sampel air versus stasiun pengamatan di semua lokasi sampling ini lebih tinggi daripada sampel sedimen, hal ini akan diperjelas jika dilihat nilai faktor distribusinya $\mathrm{F}_{\mathrm{D}}$ dalam Tabel 3 . 
Studi hubungan antara sebaran dan beban pencemaran radioaktivitas sampel lingkungan terhadap baku mutu dan daya tampung sungai Code Yogyakarta.

Tabel 3. Faktor distribusi air aktivitas gross $\beta$ dari air ke sedimen sungai Code

\begin{tabular}{|c|c|c|c|}
\hline \multirow{2}{*}{ Stasiun } & \multicolumn{2}{|c|}{ Aktivitas Rerata } & \multirow{2}{*}{$\begin{array}{c}\text { Faktor Distribusi } \\
F_{\mathrm{D}}(\mathrm{Liter} / \mathrm{kg})\end{array}$} \\
\cline { 2 - 3 } & Sampel air $(\mathrm{Bq} / \mathrm{liter})$ & Sampel Sedimen $(\mathrm{Bq} / \mathrm{kg})$ & 3671,949 \\
\hline \hline 1 & 0,079 & 290,084 & 3659,025 \\
\hline 2 & 0,080 & 292,722 & 2953,590 \\
\hline 3 & 0,100 & 295,359 & 2004,220 \\
\hline 4 & 0,150 & 300,633 & 2051,105 \\
\hline 5 & 0,153 & 313,819 & 2079,276 \\
\hline 6 & 0,156 & 324,367 & 2028,562 \\
\hline 7 & 0,169 & 342,827 & 1727,320 \\
\hline 8 & 0,200 & 345,464 & 1673,795 \\
\hline 9 & 0,219 & 366,561 & 1593,502 \\
\hline 10 & 0,235 & 374,473 & 1746,962 \\
\hline 11 & 0,237 & 414,030 & $\bar{A}$ \\
\hline
\end{tabular}

Keterangan : Faktor distribusi $F_{D}$ radionuklida pada sedimen $(L / k g): F_{D}=\frac{\overline{A j} \text { sedimen }}{\overline{A j} \text { air }}$

Dimana: $\overline{\text { Aj sedimen }}=$ Aktivitas jenis rerata pada sedimen $(\mathrm{Bq} / \mathrm{kg})$ dan

$\overline{\mathrm{Aj}}$ Air $=$ Aktivitas jenis rerata pada air $(\mathrm{Bq} / \mathrm{L})$

Dari Tabel 3 di atas terlihat nilai $F_{D}$ dari hulu ke hilir mengecil, artinya kenaikan nilai radioaktivitas pada sampel air lebih tajam dari pada sampel sedimen. Hal ini diduga bahwa masuknya polutan/cemaran ke dalam air sepanjang sungai Code lebih besar dari pada cemaran yang masuk ke sedimennya, artinya air buangan (dari domestik, lahan pertanian dan industri) yang masuk ke sungai mempunyai kenaikan nilai radioaktivitas yang tajam kearah hilir. Kejadian ini juga terjadi pada aktivitas radionuklida alam ${ }^{40} \mathrm{~K}$ sebagiamana dipaparkan dalam Tabel 5 .

\section{Pola sebaran aktivitas Gross Gamma $(\gamma)$}

Identifikasi radionuklida dilakukan untuk mengetahui jenis radionuklida yang terkandung/dapat terdeteksi di dalam sampel air dan sedimen sungai. Hal ini bertujuan agar dapat diketahui sumber radionuklida tersebut, dan mempermudah dalam menangani permasalahan pencemaran radioaktif yang mungkin timbul dengan adanya radionuklida di perairan sungai Code Yogyakarta. Dari hasil pencacahan dengan menggunakan spektrometer gamma dapat teridentifikasi radionuklida yang terkandung dalam sampel air maupun sedimen di perairan sungai Code sebagaimana ditunjukan dalam Tabel 4.

Tabel 4. Radionuklida yang teridentifikasi dalam sampel air dan sedimen sungai Code Yogyakarta

\begin{tabular}{|l|l|c|c|c|}
\hline No & Tenaga (keV) & Radionuklida & Waktu Paruh (Tahun) & Sumber Deret Alam \\
\hline 1 & 46,7 & ${ }^{210} \mathrm{~Pb}$ & 22,3 & ${ }^{210} \mathrm{~Pb}$ \\
\hline 2 & 186,2 & ${ }^{226} \mathrm{Ra}$ & 10 & ${ }^{226} \mathrm{Ra}$ \\
\hline 3 & 238,6 & ${ }^{212} \mathrm{~Pb}$ & $1,2 \times 10^{-3}$ & ${ }^{232} \mathrm{Th}$ \\
\hline 4 & 351,99 & ${ }^{214} \mathrm{~Pb}$ & $5,09 \times 10^{-5}$ & ${ }^{238} \mathrm{U}$ \\
\hline 5 & 583,1 & ${ }^{208} \mathrm{~T}$ & $5,81 \times 10^{-6}$ & ${ }^{232} \mathrm{Th}$ \\
\hline 6 & 609,3 & ${ }^{214} \mathrm{Bi}$ & $3,79 \times 10^{-5}$ & ${ }^{238} \mathrm{U}$ \\
\hline 7 & 911 & ${ }^{228} \mathrm{Ac}$ & $6,9 \times 10^{-4}$ & ${ }^{232} \mathrm{Th}$ \\
\hline 8 & 1460,7 & ${ }^{40} \mathrm{~K}$ & $1,265 \times 10^{9}$ & ${ }^{40} \mathrm{~K}$ \\
\hline
\end{tabular}

Dari tabel 4 , diperlihatkan adanya 8 jenis radionuklida yang teridentifikasi, yaitu: $:{ }^{210} \mathrm{~Pb},{ }^{226} \mathrm{Ra},{ }^{212} \mathrm{~Pb},{ }^{214} \mathrm{~Pb}$, ${ }^{208} \mathrm{TI},{ }^{214} \mathrm{Bi},{ }^{228} \mathrm{Ac}$, dan ${ }^{40} \mathrm{~K}$, dimana kesemua jenis radionuklida tersebut merupakan radionuklida alam yang diperkirakan berasal dari batuan (material) letusan gunung merapi yang tersebar di sepanjang Sungai, dari primordial atau lapisan tanah/sedimen yang terlarut ataupun dari aktivitas penduduk yang menyebabkan terjadinya polusi (misal : limbah industri, limbah domestik, dan pertanian). Dalam kondisi normal, radiasi alam 
Studi hubungan antara sebaran dan beban pencemaran radioaktivitas sampel lingkungan terhadap baku mutu dan daya tampung sungai Code Yogyakarta

mempunyai kontribusi terbesar dalam jumlah dosis yang diterima lingkungan setiap saat, yakni $87 \%$ dari total dosis radiasi yang diterima tubuh ataupun lingkungan berasal dari radiasi alam, dan hanya $13 \%$ dari total radiasi yang diterima berasal dari sumber-sumber radiasi buatan manusia.

Selanjutnya berdasarkan aktivitas jenis rata-ratanya dapat diperoleh perbandingan tingkat radioaktivitas tiap radionuklida alam dari setiap lokasi pengukuran beserta pola penyebarannya, dapat dilihat pada uraian berikut .

Untuk menggambarkan pola distribusi aktivitas jenis radionuklida dapat dilakukan dengan menggunakan software MS Excell (kurva garis atau batang dari lokasi hulu, tengah sampai hilir dipaparkan Gambar 4 sampai dengan Gambar 9) maupun dengan software Surfer (Gambar 10 dan 11 sebagaimana salah satu contoh radionuklida $\mathrm{K}-40$ ) sebagai berikut.

\section{Timbal (Pb)}

Peningkatan konsentrasi timbal yang terdeteksi dalam sampel air sungai dari hulu ke hilir beserta pola penyebarannya adalah sebagai berikut :

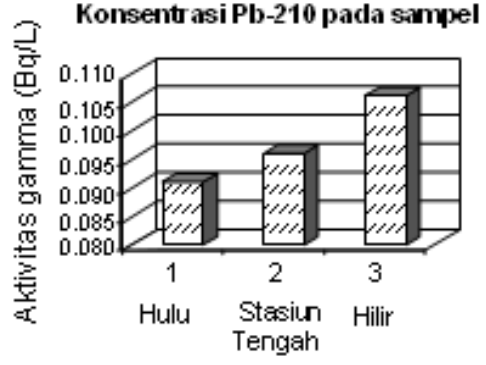

Keterangan:

$$
1=\text { Stasiun 1, } 2 \text { dan } 3=\text { Stasiun } 4,5,6,7 \text {, dan } 8
$$

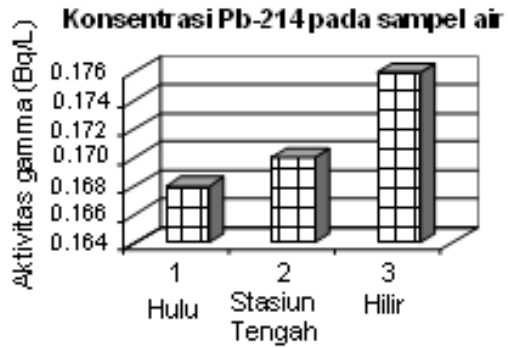

$3=$ Stasiun 9, 10 dan 11

Gambar 4. Aktivitas ${ }^{210} \mathrm{~Pb},{ }^{212} \mathrm{~Pb}$ dan ${ }^{214} \mathrm{~Pb}$ pada sampel air.

Terlihat pada Gambar 4, bahwa kandungan radionuklida ${ }^{210} \mathrm{~Pb},{ }^{212} \mathrm{~Pb}$ dan ${ }^{214} \mathrm{~Pb}$ pada air sungai semakin ke hilir semakin meningkat. Konsentrasinya pun di daerah hulu juga sudah cukup besar, hal ini dikarenakan unsur $\mathrm{Pb}$ (timbal) cukup banyak terdapat di alam dalam bentuk batuan dan mineral, polutan dari sisa-sisa accu/baterai, bahan bakar fosil, zat pewarna dan sebagainya.

\section{Radium $\left({ }^{226} \mathrm{Ra}\right)$}

Peningkatan konsentrasi Radium $\left({ }^{226} \mathrm{Ra}\right)$ yang terdeteksi dalam sampel air dan sedimen sungai dan pola penyebarannya dari hulu ke hilir adalah sebagai berikut :
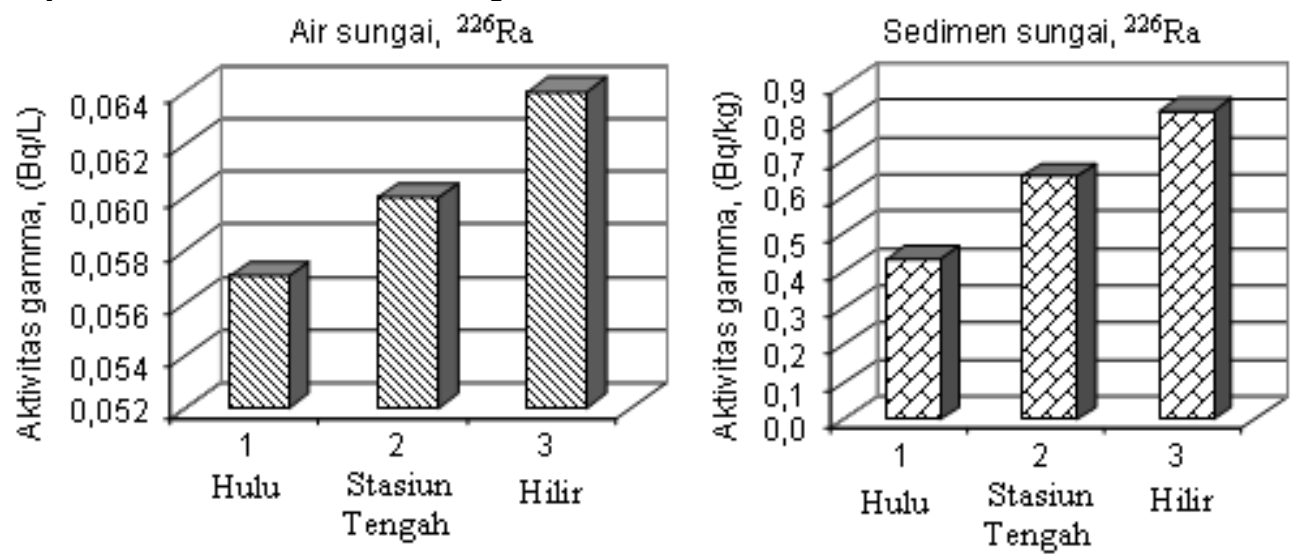

Gambar 5. Aktivitas ${ }^{226}$ Ra pada sampel air dan sedimen sungai. 
Studi hubungan antara sebaran dan beban pencemaran radioaktivitas sampel lingkungan terhadap baku mutu dan daya tampung sungai Code Yogyakarta.

Terlihat pada Gambar 5, bahwa kandungan radionuklida Radium $\left({ }^{226} \mathrm{Ra}\right)$ pada air maupun sedimen sungai semakin ke hilir semakin meningkat dengan kenaikan yang cukup signifikan, yaitu $\pm 12,28 \%$ untuk sampel air dan $92,34 \%$ untuk sampel sedimen. Peningkatan radionuklida Radium $\left({ }^{226} \mathrm{Ra}\right)$ dapat berasal dari pelapukan batuan kapur atau sisa-sisa batuan beku disepanjang sungai Code dari hulu hingga hilir.

\section{Thallium $\left({ }^{208} \mathrm{TI}\right)$}

Peningkatan konsentrasi Thallium $\left({ }^{208} \mathrm{TI}\right)$ yang terdeteksi dalam sampel air dan sedimen sungai beserta pola penyebarannya dari hulu ke hilir dapat dilihat Gambar 6 di bawah ini :
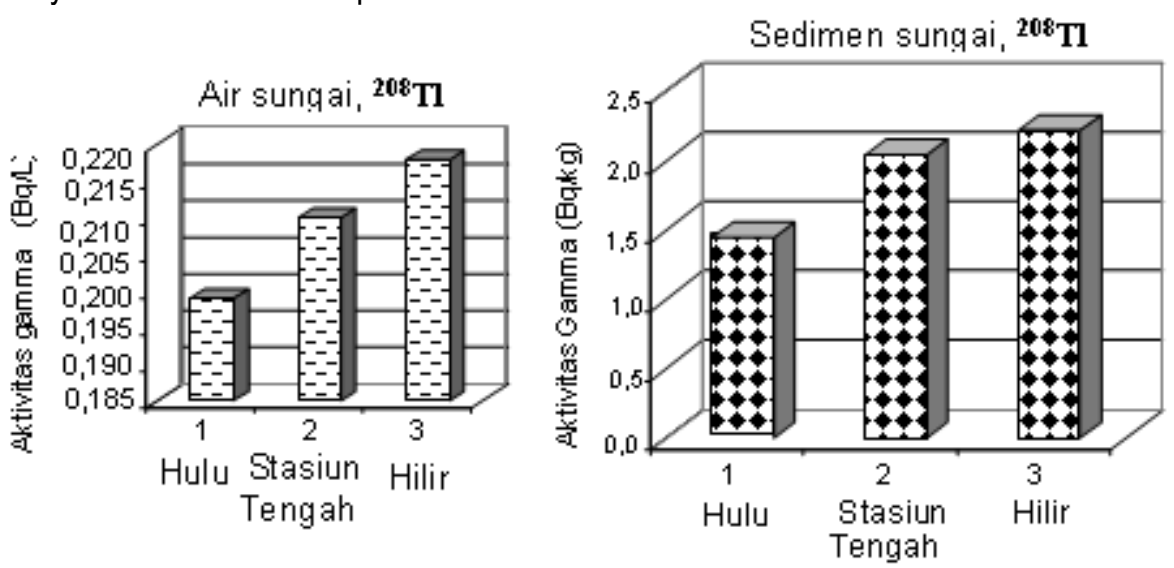

Gambar 6. Aktivitas ${ }^{208} \mathrm{Tl}$ sampel air dan sedimen

Terlihat bahwa kandungan radionuklida Thallium $\left({ }^{208} \mathrm{TI}\right)$ pada air maupun sedimen sungai semakin ke hilir semakin meningkat dengan kenaikan yang cukup signifikan, yaitu $\pm 9,55 \%$ untuk sampel air dan $53,28 \%$ untuk sampel sedimen.

\section{Bismuth $\left({ }^{214} \mathrm{Bi}\right)$}

Peningkatan konsentrasi Bismuth $\left({ }^{214} \mathrm{Bi}\right)$ yang terdeteksi dalam sampel air dan sedimen sungai beserta pola penyebarannya dari hulu ke hilir dapat dilihat pada Gambar 7 berikut :
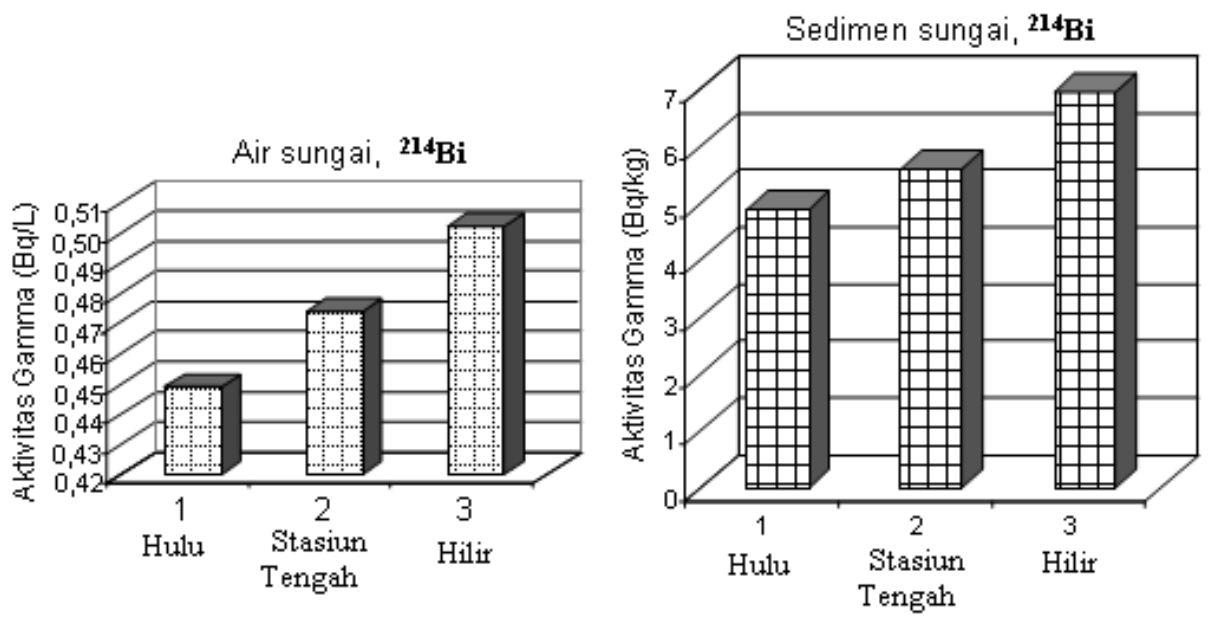

Gambar 7. Aktivitas ${ }^{214}$ Bi pada sampel air dan sedimen

Terlihat bahwa kandungan radionuklida Bismuth $\left({ }^{214} \mathrm{Bi}\right)$ pada air maupun sedimen sungai semakin ke hilir semakin meningkat dengan kenaikan yang cukup signifikan, yaitu $\pm 11,8 \%$ untuk sampel air dan $42,18 \%$ untuk sampel sedimen. 
Studi hubungan antara sebaran dan beban pencemaran radioaktivitas sampel lingkungan terhadap baku mutu dan daya tampung sungai Code Yogyakarta

\section{Actinium ( $\left.{ }^{228} \mathrm{Ac}\right)$}

Peningkatan konsentrasi Actinium $\left.{ }^{228} \mathrm{Ac}\right)$ yang terdeteksi dalam sampel air dan sedimen sungai beserta pola penyebarannya dari hulu ke hilir dapat dilihat pada Gambar 8 berikut :
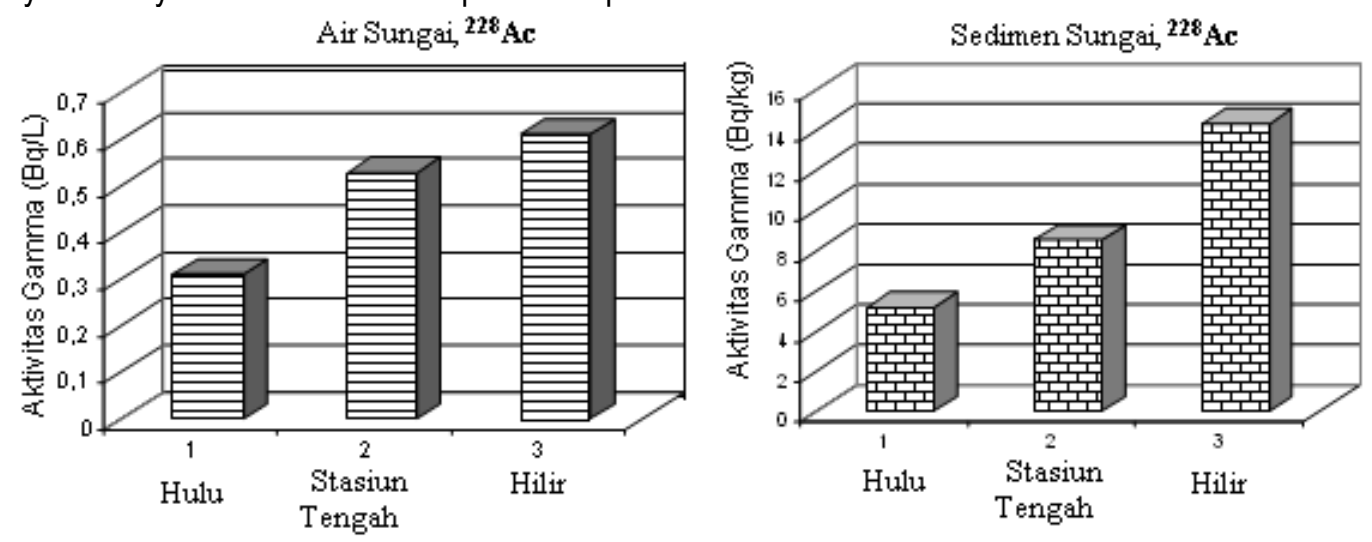

Gambar 8. Aktivitas ${ }^{228}$ Ac pada sampel air dan sedimen

Terlihat bahwa kandungan radionuklida Actinium $\left.{ }^{228} \mathrm{Ac}\right)$ pada air maupun sedimen sungai semakin ke hilir semakin meningkat dengan kenaikan yang cukup signifikan, yaitu $\pm 97,1 \%$ untuk sampel air dan $175,1 \%$ untuk sampel sedimen.

\section{Radionuklida Kalium $\left({ }^{40} \mathrm{~K}\right)$}

Besarnya konsentrasi peningkatan Kalium $\left({ }^{40} \mathrm{~K}\right)$ yang terdeteksi dalam sampel air dan sedimen sungai Code beserta pola penyebarannya dari hulu ke hilir dapat dilihat pada Gambar 9.
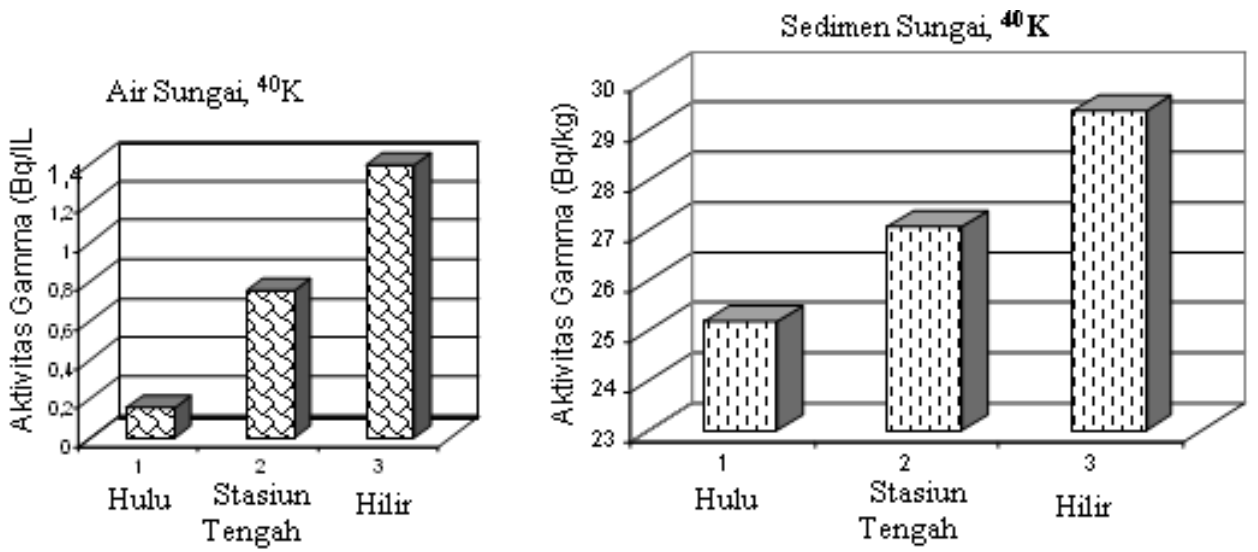

Gambar 9. Aktivitas Kalium $\left({ }^{40} \mathrm{~K}\right)$ pada sampel air dan sedimen

Terlihat pada Gambar 9, bahwa kandungan radionuklida Kalium $\left({ }^{40} \mathrm{~K}\right)$ pada air maupun sedimen sungai Code semakin ke hilir semakin meningkat dengan kenaikan yang cukup signifikan.

Untuk memperjelas prosentase kenaikan radioaktivitas ${ }^{40} \mathrm{~K}$ dapat dilihat pada Tabel 5 serta dengan program soft ware Surfer didapat Gambar 10 dan 11.

Dari Tabel 5 terlihat bahwa kandungan radionuklida Kalium $\left({ }^{40} \mathrm{~K}\right)$ pada air maupun sedimen sungai Code semakin ke hilir semakin meningkat dengan kenaikan yang cukup signifikan, yaitu $\pm 822,52 \%$ untuk sampel air dan $16,7 \%$ untuk sampel sedimen. Adanya unsur radionuklida ${ }^{40} \mathrm{~K}$ ini dalam perairan sungai Code diduga berasal dari tanah permukaan bumi sendiri dan air hujan/mata air yang telah tercemar dalam kegiatan penggunaan pupuk dan pestisida pada areal pertanian/persawahan/ perkebunan di daerah hulu, diketahui radionuklida Kalium $\left({ }^{40} \mathrm{~K}\right)$ ini banyak terkandung dalam sayuran dan buah-buahan serta batuan/tanah/pasir. 
Studi hubungan antara sebaran dan beban pencemaran radioaktivitas sampel lingkungan terhadap baku mutu dan daya tampung sungai Code Yogyakarta.

Tabel 5. Aktivitas ${ }^{40} \mathrm{~K}$ dan prosentase peningkatan-nya pada sampel air dan sedimen

\begin{tabular}{|c|c|c|}
\hline Keterangan & Sampel Air (Bq/liter) & Sampel Sedimen $(\mathrm{Bq} / \mathrm{kg})$ \\
\hline \multicolumn{3}{|l|}{ Aktivitas: } \\
\hline Hulu & 0,151 & 25,18 \\
\hline Tengah & 0,751 & 27,069 \\
\hline Hilir & 1,393 & 29,384 \\
\hline \multicolumn{3}{|l|}{$\%$ Peningkatan } \\
\hline Hulu ke Tengah & 397,35 & 7,5 \\
\hline Tengah ke Hilir & 85,49 & 8,5 \\
\hline Hulu ke Hilir & 822,52 & 16,7 \\
\hline
\end{tabular}

Kenaikan aktivitas ${ }^{40} \mathrm{~K}$ dari hulu ke hilir dalam sampel air sangat tinggi (tajam), sebaliknya untuk sampel sedimen kenaikan aktivitasnya hanya rendah. Untuk memperjelas kenaikan aktivitas ini digunakan program Surfer software sebagaimana dapat dilihat pada grafik dan gambar pada Gambar 10 dan 11.
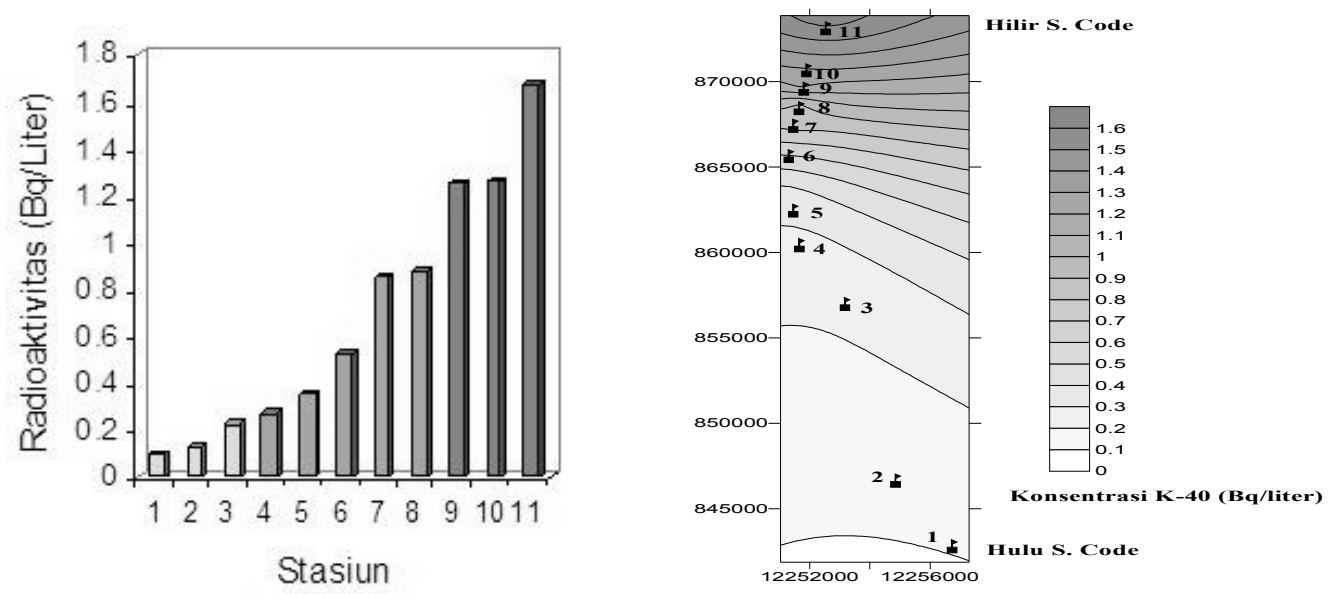

Gambar 10. Diagram peningkatan konsentrasi ${ }^{40} \mathrm{~K}$ dan pola penyebarannya untuk ampel air sungai Code.
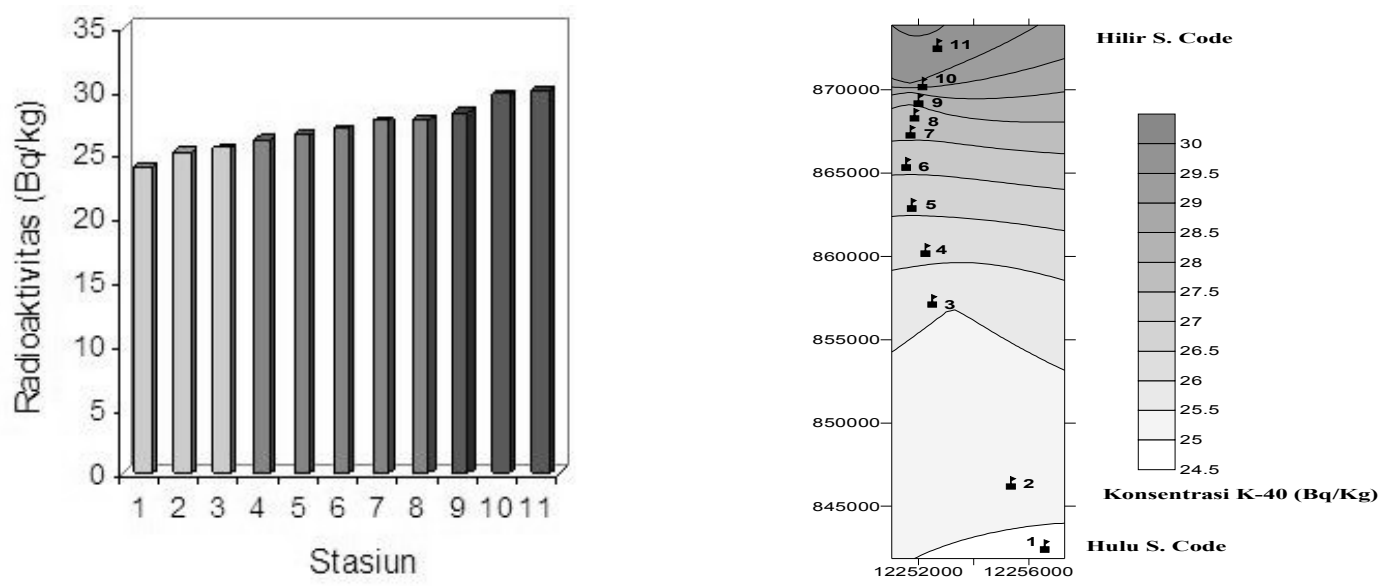

Gambar 11. Diagram peningkatan konsentrasi ${ }^{40} \mathrm{~K}$ dan pola penyebarannya untuk Sampel sedimen sungai Code

\section{Daya Tampung Sungai}

Untuk menentukan daya tampung sungai terhadap beban pencemarnya yaitu nilai aktivitas/ konsentrasi dari parameter kimia air yang terukur dibandingkan dengan baku mutu tingkat radioaktivitas menurut Keputusan Kepala Badan Pengawas Tenaga Nuklir 02/Ka-BAPETEN/V-99 untuk radioaktivitas di lingkungan. Radionuklida yang dianalisis disini adalah ${ }^{210} \mathrm{~Pb},{ }^{212} \mathrm{~Pb},{ }^{228} \mathrm{Ac}$ dan ${ }^{226} \mathrm{Ra}$ karena hanya keempat radionuklida tersebut yang 
Studi hubungan antara sebaran dan beban pencemaran radioaktivitas sampel lingkungan terhadap baku mutu dan daya tampung sungai Code Yogyakarta

diketahui nilai baku mutunya. Perhitungan beban pencemaran sungai dan daya tampungnya untuk masingmasing parameter radionuklida memakai rumus Persamaan 1. Hasil perhitungan tersebut ditampilkan dengan Gambar 12:
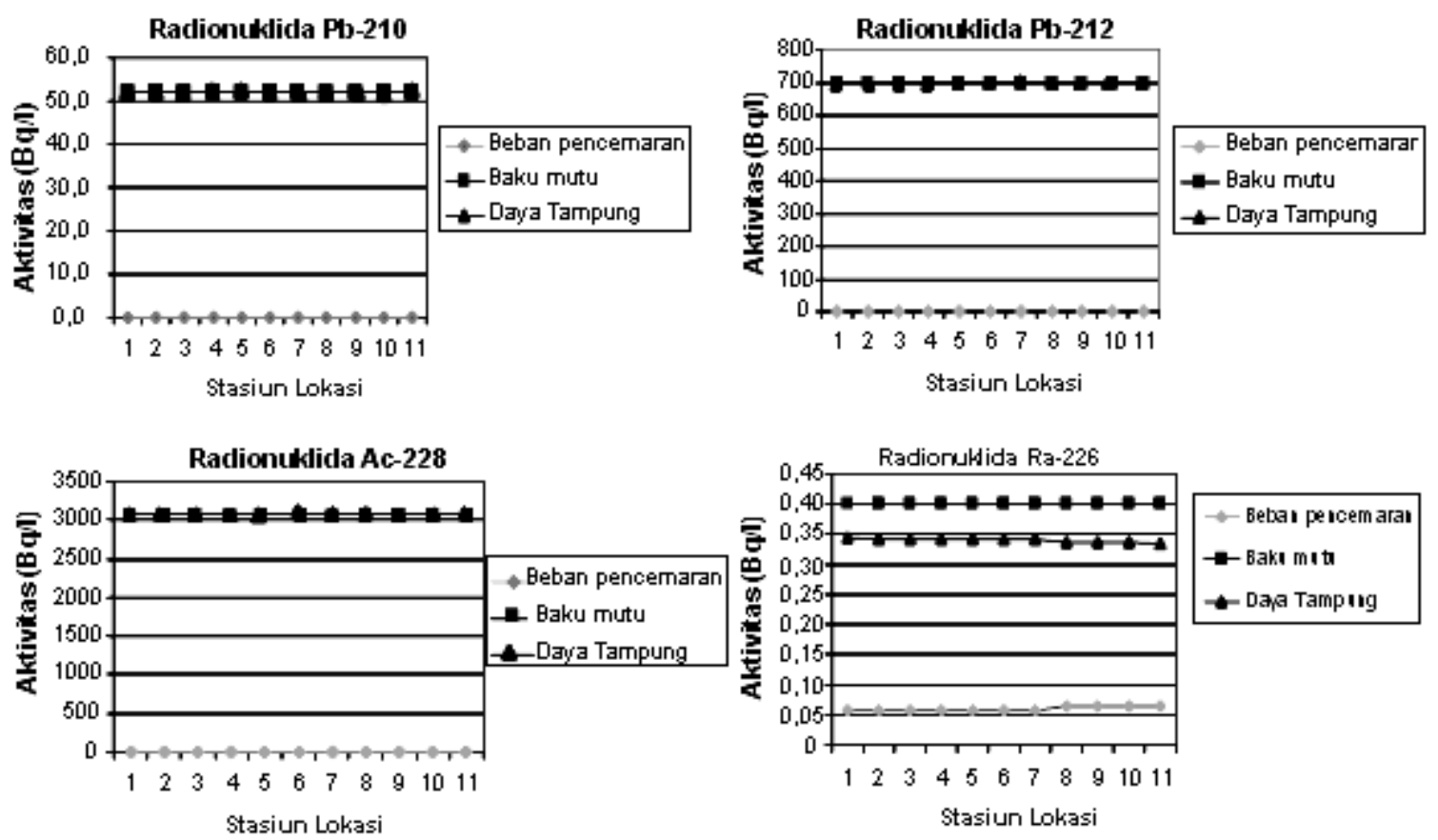

Gambar 12. Grafik daya tampung sungai menurut keputusan Kepala Badan Pengawas Tenaga Nuklir 02/KaBAPETEN/V-99 tentang baku mutu radioaktivitas di lingkungan.

Dari Gambar 12 tersebut dapat diketahui bahwa beban pencemaran untuk radionuklida ${ }^{210} \mathrm{~Pb}$ pada lokasi antara Turgo sampai Pacar berada dibawah angka baku mutu air sungai untuk radioaktivitas. Hal ini menunjukkan bahwa daya tampung sungai masih baik. Beban pencemaran untuk radionuklida ${ }^{212} \mathrm{~Pb}$ juga berada di bawah angka baku mutu air sungai untuk radioaktivitas. Hal ini menunjukkan bahwa daya tampung sungai baik. Begitu juga untuk radionuklida ${ }^{226} \mathrm{Ra}$ dan ${ }^{228} \mathrm{Ac}$ diketahui bahwa beban pencemaran berada di bawah angka baku mutu air sungai untuk radioaktivitas, berarti sungai masih memiliki daya tampung yang baik dari hulu ke hilir.

\section{KESIMPULAN}

Berdasarkan hasil analisis data, maka dapat diambil beberapa kesimpulan, yaitu:

1. Pola sebaran aktivitas Gross $\llbracket$ : tertinggi dari sampel air maupun sedimen sungai adalah pada daerah hilir yang meliputi daerah di sekitar stasiun Ring Road Selatan, stasiun Abang Ngoto, serta stasiun Pacar Wonokromo. Dari arah hulu ke hilir prosentase kenaikan radioaktivitas gross $\llbracket$ sampel air lebih tinggi daripada sampel sedimen.

2. Pola sebaran aktivitas rerata radionuklida alam pemancar Gamma (ם), tingkat aktivitas rerata tiap radionuklida pada sampel air ataupun sedimen sungai Yogyakarta semakin ke daerah hilir semakin besar. Dari arah hulu ke hilir prosentase kenaikan radioaktivitas 40K sampel air lebih tinggi daripada sampel sedimen.

3. Grafik garis beban pencemaran, baku mutu dan daya tampung dari radionuklida yaitu $210 \mathrm{~Pb}, 212 \mathrm{~Pb}$, 226Ra dan 228Ac, ditunjukkan Grafik Beban Pencemaran berada dibawah Grafik Angka Baku Mutu air sungai menurut keputusan Kepala Badan Pengawas Tenaga Nuklir 02/Ka-BAPETEN/V-99 tentang baku mutu radioaktivitas, berarti sungai masih memiliki daya tampung yang baik dari hulu ke hilir dan masih dapat menerima beban pencemaran keempat radionuklida tersebut. 


\section{DAFTAR PUSTAKA}

1. AGUS TAFTAZANI. Usulan Kegiatan 2005-2006, Program Kali Bersih (Prokasih) Sungai Yogyakarta, Kerjasama BATAN-Bapedalda DIY-IAEA 2005, Yogyakarta 2005.

2. ANONIM. Peraturan Pemerintah RI No.82. Tahun 2001, Jakarta 2001.

3. ANONIM. SK Men. KLH. No.110/2003, Jakarta 2003.

4. ANONIM. Keputusan Kepala Badan Pengawas Tenaga Nuklir 02/Ka-BAPETEN/V-99 tentang Baku Mutu radioaktivitas di lingkungan, Jakarta 1999.

5. AGUS TAFTAZANI, SUMINING dan AGUS PUDJOARINTO. Pola Penyebaran Radioaktivitas $\alpha, \beta$ dan Kandungan Radionuklida Dalam Cuplikan Kerang Hijau (Mytilus viridis L), Sedimen dan Air Laut di Pantai Ceribon dan Pantai Losari Jawa Barat. Prosiding Pertemuan dan Presentasi IImiah Litdas Iptek Nuklir. P3TM-BATAN, Yogyakarta 25-26 Juli 2000,

6. AGUS TAFTAZANI, DWI P. SASONGKO, KRIS TRI BASUKI,. Radioaktivitas Lingkungan Pesisisir Laut Semarang. Prosiding Temu IImiah Jaringan Kerjasama Kimia Indonesia (JASAKIAI) Seminar Nasional VI. Kimia Dalam Industri dan Lingkungan Buku I. Yogyakarta 16-17 Desember 1997.

7. AGUS TAFTAZANI. "Analisis Pengelompokan Stasiun berdasarkan aktivitas gamma $\gamma$, radionuklida pada sampel air dan sedimen sungai Code Yogyakarta" belum terbit, Yogyakarta 2005. 